
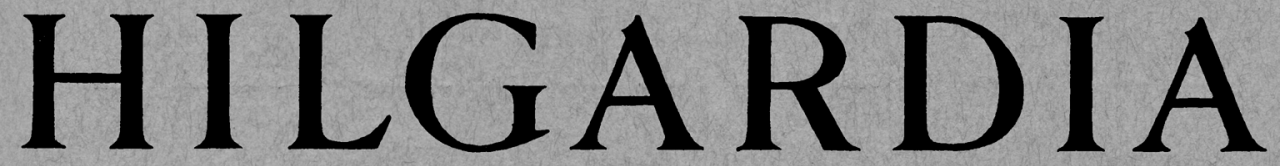

A Journal of Agricultural Science Published by the California Agricultural Experiment Station

CONTENTS

EFFECT OF DOWNY MILDEW

ON PRODUCTIVITY OF SUGAR BEETS, AND SELECTION FOR RESISTANCE

\author{
L. D. LEACH
}

CERTAIN SYMPTOMS RESEMBLING THOSE OF CURLY TOP OR ASTER YELLOWS, INDUCED BY SALIVA OF XEROPHLOEA VANDUZEEI

HENRY H. P. SEVERIN, F. DOUGLAS HORN, and NORMAN W. FRAZIER 
CERTAIN SYMPTOMS RESEMBLING THOSE OH CURLY TOP OR ASTER YELLOWS, INDUCED BY SALIVA OF XEROPHLOEA

VANDUZEEI

HENRY H. P. SEVERIN, F. DOUGLAS HORN, AND NORMAN W. FRAZIER 



\section{CERTAIN SYMPTOMS RESEMBLING THOSE OF CURLY TOP OR ASTER YELLOWS, INDUCED BY SALIVA OF XEROPHLOEA VANDUZEEI}

HENRY H. P. SEVERIN, ${ }^{2}$ F. DOUGLAS HORN, AND NORMAN W. FRAZIER"

\section{INTRODUCTION}

IN 1938, during an investigation of leafhopper species to determine which were vectors of aster-yellows virus, Xerophloea vanduzeei Law., was tested. This insect was at first thought to be a vector, for after feeding on infected asters it produced, in healthy plants, some symptoms closely resembling those of aster yellows. Further preliminary tests, however, showed the same results even when the insect had been reared entirely on healthy asters and was presumably noninfective for yellows. When the insect was tested on sugar beets, it caused some symptoms resembling those of curly top, even though it had not previously been allowed to feed on curly-top-infected plants.

The disease produced by the feeding of this insect is not likely to be of commercial importance on either beets or asters. In twenty-eight years of work on curly top, the senior author has never taken Xerophloea vanduzeei on beets in the field, nor observed it on asters under natural conditions. It has been collected, however, in alfalfa fields. Nevertheless, the fact that diseases so closely simulating curly top and aster yellows could be produced when apparently these viruses are not involved suggests that definite identification of these two virus diseases is not possible from symptoms alone. Furthermore, similar situations may exist with other sucking insects or other syndromes. A brief review of the literature follows.

\section{REVIEW OF LITERATURE}

Ball (1918) ${ }^{4}$ discovered one of the most striking examples of a plant disease, namely hopperburn of potato induced by the potato leafhopper, Empoasca fabae (Harris). He (Ball, 1919) concluded that the explanation of the disease was to be found in "some specific transmitted by the insect," and that the production of the disease was specific to the potato leafhopper. Eyer (1922a, $1922 b$ ) and Fenton and Hartzell (1923) attribute the causative agent of hopperburn to some specific substance in the insect's body.

Ball (1919) attributes hopperburn to an "infection or an injection." Whether it will prove to be a specific disease like curly top is yet to be worked out. According to Granovsky (1928) the symptoms indicate the presence of some infective principle or virulent toxin. Johnson (1934) states that the pathological symptoms caused by the potato leafhopper on forage legumes were not due to the transmission of a virus by this insect.

\footnotetext{
${ }^{1}$ Received for publication May 8, 1944.

2 Entomologist in the Experiment Station.

${ }^{3}$ Junior Entomologist in the Experiment Station.

"See "Literature Cited" for complete data on citations, referred to in the text by author and date of publication.
} 
Granovsky $(1928,1930)$, Monteith and Hollowell (1929), and Poos (1929) suggested that the probable cause of hopperburn was some "chemical or enzymic toxin" injected by the leafhopper into the tissue of the plant, where it remained more or less localized.

Granovsky (1930) reported that a histological study of injured tissue showed a gradual disorganization and granulation of the plastids, clogging of the vascular bundles, and complete disorganization of the phloem region. Microchemical tests revealed a greater accumulation of starch grains and reducing sugars in the tissue injured by the leafhopper. He concluded that these phenomena are evidently due to enzymic secretions in the course of feeding of the leafhopper.

Later investigations by Smith and Poos (1931) and Johnson (1934) have verified the histological changes reported by Granovsky. Smith (1933) and Poos and Wheeler (1934) reported that the clogging or sheath material is secreted by the salivary glands of the leafhopper, is largely protein, and may contain chitin. These authors consider that the injection of some toxic substance into the plant during the feeding of the leafhopper remains a possibility, but it is believed to be improbable. They suggest that an overaccumulation of the carbohydrate products. of photosynthesis above the points where a plugging of the vascular tissue is caused by the leafhopper in its feeding upon the veins of the stem tips.

According to Medler (1941), plant injury by Empoasca fabae results both from the insect's habit of feeding in the vascular tissue and from the action of a specific compound which is injected during the feeding process and which causes hypertrophy in affected cells. Conceivably, the hypertrophied cells cause an interruption of translocation processes, which initiates secondary external symptoms of chlorosis or reddening in alfalfa leaves.

All investigators of hopperburn agree that the causative agent is localized in the leaves subjected to leafhopper feeding. Fenton (1921), Fenton and Hartzell (1923), and Poos (1929) suggested that the disease was not systemic. Poos and Wheeler (1943), however, proved that it was not systemic by enclosing an alfalfa plant in two cages : the shoots containing potato leafhoppers developed symptoms of the disease, and the shoots free from insects remained healthy.

In China, Wang and Yuan (1924) on the authority of Teng (1931) demonstrated that the leafhopper Empoasca biguttula Mats. = (Chlorita biguttula Mats.) was associated with crytosis, or clubleaf of cotton. Teng confirmed the causal relation of this leafhopper to the disease, which he suggested may possibly be a direct insect injury or, perhaps, a virus disease somewhat different from the ordinary. Five methods of mechanical inoculation of healthy plants gave negative results. As these writers note, it has not yet been established whether clubleaf of cotton is localized or systemic.

Stigmonose.-Woods (1900) was one of the first plant pathologists who demonstrated that the puncture of the aphid Rhopalosiphum dianthi Shrank induced a leaf-spotting disease of carnations and other pinks. He concluded that the "insect injects some irritating substance of an acid or enzymic nature in the wound, and that this substance causes the increase of oxidizing enzymes in the cells which it reaches, and that these enzymes interfere with 
the nutrition of the cell destroying the chlorophyll and setting up other changes which finally result in death."

Froghopper Blight of Sugar Cane.-Froghopper blight of sugar cane is caused by the feeding of a cercopid, or froghopper, Thomaspis saccharina Dist., and has been studied intensively by Williams (1921) and Withycombe (1926). The effects of the sucking of the froghopper are the removal of water, carbohydrates, proteins, and so forth, and the injurious effects on the border parenchyma. The injurious effects of the saliva are accomplished partly by diastatic and oxidizing enzymes. Oxidases of the plant and the saliva seem to be responsible for the color changes and production of red pigment; but more important is their effect upon the $\mathrm{H}$-ion concentration of the cell sap. Increase in transpiration may occur locally after puncture, the phloem becomes blocked, translocation is inhibited, and the metabolic equilibrium of the plant is upset. A local lesion is followed by systemic effects.

Mealybug Wilt of Pineapple.-According to Carter (1932) this disease is induced by a diffusable, systemic, toxic secretion injected into the plant by the feeding of the pineapple mealybug, Pseudococcus brevipes (Ckl.). There is no evidence for multiplication of the toxin in the plant, and recovery from wilt is commonly encountered. Evidence of antitoxic reactions on the part of the plant is available. The toxicity of a mealybug colony varied according to the host plants from which it was transferred, including the roots of grasses, and was intensified in succeeding generations reared on pineapples (1939). This is believed to result from changes in the insects' secretion, induced by the varied nutritional conditions afforded by the host plants.

Green Spotting of Pineapple.-Carter (1933) has shown that the pineapple mealybug, Pseudococcus brevipes (Ckl.), causes two types of spotting on pineapple leaves. One is chlorotic, and the other is a different type known as green spot. Colonies of mealybugs produce green spots on leaves at the point of feeding, and this ability when present in adult females was transmitted to the young; but this capacity was absent in mealybugs from the roots of certain grasses. Green spotting is not a symptom of pineapple wilt, but is a local, toxic effect of the feeding of a strain of $P$. brevipes. Mealybugs that induce green spots are dark gray, this shade being caused by the presence of a dark-colored mycetome; on the other hand, pinkish-gray forms do not cause green spotting. According to Carter $(1936,1939)$, in Hawaii the symbiont flora in the mycetome of the mealybug is clearly associated with the ability to produce green spots.

Ito (1938) found 2 strains of Pseudococcus brevipes: the gray form, which causes green spotting, reproduced sexually, producing both males and females, whereas the nongreen spotting form reproduced parthenogenetically, producing only females.

Psyllid Yellows.-Psyllid yellows is produced only by the nymphs of Paratrioza cockerelli Sulc.; the adult is incapable of producing the disease. Binkley (1929) concluded that the disease was caused by a virus. Shapovalov (1929) observed what he thought was tuber transmission of the disease in potato, but Richards and Blood (1933) failed to transmit psyllid yellows through the tuber. According to Richards and Blood, the most plausible explanation of the cause of the disease is as follows : the nymphs during their feeding process 
inject into the plant tissue some toxic substance ; this quickly becomes systemic and possibly produces the exaggerated responses characteristic of the disease by interfering in some way with the carbohydrate metabolism of the plant.

Anasa Wilt of Cucurbits.-According to Robinson and Richards (1931), squash and pumpkin growing had been completely abandoned in many parts of Utah owing to a peculiar wilt which is caused by the feeding of the squash bug, Anasa tristis DeG. Wilting results in 1 to 16 days, the time depending upon the age of the plant, the progress of the season, and the number of insects feeding. Wilting results only above the point of insect contact, whether the petiole or the entire stem is exposed to feeding. When wilting is not too complete, plants uniformly recover upon the removal of the insects. These workers suggest the possibility that a toxic substance injected by the insect during the process of feeding is involved.

In 1938 an investigation was undertaken to learn the nature of the injury caused by the feeding of Xerophloea vanduzeei-whether it is a virus disease, a mechanical injury, or the effect of a toxic secretion by the insect. The life history of the insect was studied. The symptoms of the disease on sugar beet and on aster were observed in detail, and experiments were performed to determine whether the effects were local or systemic. Tests were made to transmit the disease from affected plants to healthy beets or asters by known curly-top or aster-yellows vectors and by mechanical inoculation. There were further attempts to ascertain whether this species is a vector of the curly-top and aster-yellows viruses.

\section{MATERIALS AND METHODS}

The production of noninfective beet leafhoppers, Eutettix tenellus (Baker), was first described by Stahl and Carsner (1918) and Severin (1930); that of noninfective short-winged aster leafhoppers, Macrosteles divisus (Uhl.), and long-winged aster leafhoppers, a race of the same species, by Severin (1929b, 1940, 1942).

The preparations of plant extracts and centrifugation have been described by Severin and Freitag (1933).

One method of mechanical inoculation used is that described by Rawlins and Tompkins (1936). Shortly after inoculation the carborundum was washed from the leaves with water. The flamed-needle method of inoculation with a cotton swab near the point was also employed (Severin, 1924).

\section{DISTRIBUTION, FOOD PLANTS, AND LIFE HISTORY OF XEROPHLOEA VANDUZEEI}

The genus Xerophloea, erected by Germar in 1839, belongs to the subfamily Gyponinae. According to Lawson (1931), color and genitalia are of little or no value in the identification of this genus. The shape of the vertex and the degree of inflation of the front are dependable characteristics. These, along with size and geographical distribution, were sufficient to enable a proper differentiation of the several species.

In its geographical distribution, Xerophloea vanduzeei is limited to California.

The species was commonly collected on Australian saltbush (Atriplex semi- 
baccata) in the Imperial, Salinas, and San Joaquin valleys. It has also been taken on weeds growing in grain stubble fields in the Sacramento and Santa Clara valleys. Specimens were also captured on nettleleaf goosefoot (Chenopodium murale) and rough pigweed (Amaranthus retroflexus) in Los Angeles County, puncture vine (Tribulus terrestris) and a burweed (Franseria acanthicarpa) in Tulare County, and yellow star thistle (Centaurea solstitialis) in Sonoma County. Among economic plants it has been taken on alfalfa, grapevines, and vetch.

Oviposition.-Under greenhouse conditions the ovipositing female cuts an incision in the petiole, midrib, or lateral veins of the sugar-beet leaves and

TABLE 1

DUtation OF NyMPHAL Stadia of Xerophloea vanduzeei

\begin{tabular}{|c|c|c|c|c|c|c|c|}
\hline \multirow{2}{*}{ Sex and date hatched } & \multicolumn{6}{|c|}{ Duration of stadia } & \multirow{2}{*}{ Total } \\
\hline & 1st instar & $2 \mathrm{~d}$ instar & 3d instar & 4th instar & 5th instar & 6th instar & \\
\hline \multirow{2}{*}{\multicolumn{8}{|c|}{ Males: }} \\
\hline & & & & & & & \\
\hline April $28 \ldots \ldots \ldots \ldots \ldots \ldots \ldots \ldots$ & 16 & 10 & $\mathbf{5}$ & 9 & 11 & .. & 52 \\
\hline April $22 \ldots \ldots \ldots \ldots \ldots \ldots \ldots$ & 15 & 12 & 9 & 9 & 13 & .. & 57 \\
\hline April $14 . \ldots \ldots \ldots \ldots \ldots \ldots \ldots$ & 11 & 12 & 9 & 8 & 18 & .. & 58 \\
\hline April $19 \ldots \ldots \ldots \ldots \ldots \ldots \ldots \ldots$ & 14 & 11 & 8 & 12 & 13 & .. & 58 \\
\hline April $26 \ldots \ldots \ldots \ldots \ldots \ldots \ldots \ldots$ & 15 & 12 & 9 & 9 & 14 & .. & 61 \\
\hline April $12 \ldots \ldots \ldots \ldots \ldots \ldots \ldots \ldots$ & 14 & 13 & 11 & 11 & 16 & .. & 65 \\
\hline 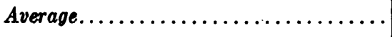 & 12.7 & 10.8 & 8.6 & 8.8 & 14.2 & .. & 58.3 \\
\hline \multicolumn{8}{|l|}{ Females: } \\
\hline April $22 \ldots \ldots \ldots \ldots \ldots$ & 15 & 14 & 13 & 14 & 10 & .. & 65 \\
\hline April $14 \ldots \ldots \ldots \ldots \ldots$ & 14 & 15 & 13 & 14 & 10 & .. & 66 \\
\hline April $22 \ldots \ldots \ldots \ldots \ldots \ldots \ldots \ldots$ & 17 & 12 & 10 & 11 & 17 & .. & 67 \\
\hline April $12 \ldots \ldots \ldots \ldots \ldots \ldots \ldots \ldots$ & 17 & 9 & 11 & 15 & 15 & .. & 67 \\
\hline April $28 \ldots \ldots \ldots \ldots \ldots \ldots \ldots \ldots$ & 12 & 13 & 10 & 9 & 14 & 12 & 70 \\
\hline April $28 \ldots \ldots \ldots \ldots \ldots \ldots \ldots$ & 16 & 10 & 18 & 13 & 17 & .. & 74 \\
\hline 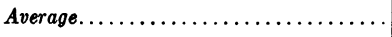 & 15.1 & 12.1 & 12.5 & 12.7 & 13.8 & 12.0 & 68.2 \\
\hline
\end{tabular}

embeds a single egg in this slitlike chamber. Oviposition in the field has not been observed by the present authors.

$E g g$.-The egg after deposition averages $2.75 \mathrm{~mm}$ long, $0.5 \mathrm{~mm}$ wide. It is elongated, narrower at one end than at the other, with the dorsal and ventral surfaces differently curved. As the hatching period draws near, the anterior pole may protrude from the mouth of the egg chamber, and the pink eyes of the embryo may be visible. After hatching, the eggshells usually protrude from the mouth of the egg chambers or are pulled out of those chambers and adhere to the petiole, midrib, or veins.

The slitlike incision turns brown after the egg is embedded in it, black after the egg hatches. When successive eggs are deposited in rows, the petiole sometimes cracks so that the eggs fail to hatch.

Duration of Stadia.-Table 1 indicates the duration of the nymphal stadia. The total duration of these stadia in the males is shorter than in the females. One nymph, a female, passed through six molts; all others through five.

Measurements of Instars.-Table 2 gives the average measurements of various parts of the body 1 day after hatching and 1 day after each molt. The 
diameter of the head was measured across the compound eyes, and its length along the dorsal median line. As table 2 indicates, each instar can be determined accurately by the diameter and length of the head and the length of the abdomen. Average measurements of the male and female leafhoppers that completed five molts show the males to be smaller than the females. The pink females are larger than the cream, and the cream larger than the green.

Color of Nymphal Instars.-The first nymphal instar after hatching is white, later gray (plate 1, $A$ ). The thorax and abdomen are covered with numerous hairs. The second instar is greenish gray (plate $1, B$ ). The third, fourth, and fifth instars become progressively greener (plate $1, C, D, E$ ).

TABLE 2

Color and Average Measurements of Nymphal Instars and Adults of Xerophloea vanduzeei*

\begin{tabular}{|c|c|c|c|c|c|}
\hline Nymphs and adults & $\begin{array}{c}\text { Width } \\
\text { of } \\
\text { head }\end{array}$ & $\begin{array}{c}\text { Length } \\
\text { of } \\
\text { head }\end{array}$ & $\begin{array}{l}\text { Length of } \\
\text { head and } \\
\text { abdomen }\end{array}$ & $\begin{array}{l}\text { Length } \\
\text { to end of } \\
\text { wings }\end{array}$ & Color \\
\hline \multicolumn{6}{|l|}{ Nymphs: } \\
\hline First instar. . . . . . . . . & 0.56 & 0.39 & 1.42 & $\ldots$ & Gray \\
\hline Second instar........... & 0.81 & 0.55 & 2.08 & $\ldots$ & Greenish gray \\
\hline Third instar............ & 1.11 & 0.77 & 2.83 & $\ldots$ & Green \\
\hline Fourth instar. $\ldots \ldots \ldots \ldots \ldots \ldots \ldots \ldots \ldots$ & 1.47 & 1.00 & 3.92 & $\ldots$ & Green \\
\hline Fifth instar. . . . . . . . . . . . . . . . . & 1.92 & 1.21 & 5.36 & $\ldots$ & Green \\
\hline \multicolumn{6}{|l|}{ Adults: } \\
\hline Male.. & 1.83 & 0.69 & 5.46 & 5.79 & Brown \\
\hline Female.... & 2.04 & 0.90 & 6.31 & 6.39 & Green \\
\hline Female & 2.10 & 0.88 & 6.41 & 6.62 & Pink \\
\hline Female & 2.02 & 0.85 & 6.46 & 6.52 & Cream \\
\hline
\end{tabular}

* Ten insects measured for each average.

Color of Adults.-There are four color forms of adults-brown males and green, pink, and cream-colored females (plate $1, F, G, H, I$ ). Green females that acquired the winged stage on July 3 , had faded to a straw color by September 18, when the next observation was made; but the head and the thorax were still a faded green. The cream form is different from the straw ; the cream females appear immediately after the last molt. The female offspring of single females of each of the three color forms are usually green or cream, rarely pink ; evidently, therefore, the three color forms of females belong to the same species.

On Sugar Beet.-The succession of symptoms on the sugar beet, Beta vulgaris, resulting from the feeding of 20 or more nymphs or adults is not always constant; hence each symptom will be described more or less independently of the varying sequence.

The first symptom appearing on the youngest leaves of beet seedlings may be a clearing of the veins and veinlets (plate $2, A$ ), which usually begins as a small area on one or both sides of the midrib at the basal portion of the blade, and later spreads as a network over most of the leaf. There may be an inward rolling of the margin of the youngest leaves (plate $2, D, E$ ), accompanied by 
cleared veinlets and protruding veins. These symptoms resemble those produced by the curly-top virus on the youngest leaves of sugar beets (Severin, $1929 a$ ).

The veinlets on the lower surface of the youngest leaves swell prominently, and the midrib and lateral veins protrude (plate $2, B$ ). Protuberances may appear on the upper surface of the leaves (plate 2, $C$ ), whereas in curly-top small wartlike elevations develop on the veins on the lower surface of the leaves (Severin, 1929a).

Part of the leaf becomes yellow, sometimes near the tip (plate $3, B$ ), along one or both sides of the midrib (plate $3, C$ ), or on the basal portion of the blade (plate $3, A$ ). The yellowing is characteristic of the older leaves. Within 1 or 2 days the yellow area becomes dry, resembling a "burning" of the tissue (plate $3, C, D, E)$. The yellowing spreads and is followed by drying; usually the leaf dies within 4 to 8 days. Necrosis of the midrib and veins sometimes appears when the blade is chlorotic (plate $3, D$ ). Yellowing and drying are not limited to the older leaves; the intermediate and younger leaves may also be affected. On the youngest leaves, which are more resistant, yellowing usually does not spread over more than a small area of the blade. When two or more insects feed on the petiole of an older leaf, yellowing usually appears on the blade before the cleared veinlets occur on the youngest leaves. After the symptoms first appear on either the youngest or the older leaves, the intermediate leaves become affected, and finally most of the leaves show one or more types of the symptoms described. When the nymphs or adults were removed from the beets, the newly developing leaves were normal.

Some sugar beets may develop several types of malformed leaves. The midrib may be curved (fig. 1, $A$ ) near the tip of the youngest leaves and near the base of the older leaves. The leaves may be asymmetrical (fig. 1, $B$ ); one half of the blade may be narrower than the opposite half (fig. 1, B) with an outward rolling of the margin of the dwarfed side. The basal margin of the leaf may be rolled inward (fig. 1, C). Sometimes the leaves assume a rectangular form, with or without cleared veinlets, and usually with protuberances on the upper surface of the blade.

On China Aster.-The first symptom on the youngest leaves of the China aster, Callistephus chinensis, is a clearing of the veins and veinlets (plate 4, $A, B)$, which is more sharply defined than that induced by the aster-yellows virus (plate $4, C, E$ ). Pale-yellow veinbanding, indistinguishable from that caused by the aster-yellows virus, develops later. The transparent veins appeared on the youngest leaves within 1 to 14 days after the nymphs were caged on the plants and within 3 to 32 days when adults were used (table 3 ), whereas the incubation period of aster yellows varies from 11 to 27 days and averages 18 (Severin, 1929b). After the nymphs or adults were removed from the asters, the newly developing leaves failed to show symptoms.

Sometimes the youngest leaves show small, interveinal, green, blisterlike elevations (plate $5, C$ ) ; on many host plants the viruses of common cucumber mosaic, western cucumber mosaic, and celery calico produce elevations similar to these, but not necessarily interveinal. The youngest leaves may be asymmetrical, and pale-yellow veinbanding may occur along the cleared veins and veinlets (plate $5, A, B, C$ ). 
Normal elongation of the internodes is inhibited by the causative agent, and the aster plant becomes dwarfed. Axillary shoots develop from the bud in the axils of the leaves (plate $5, D$ ), as in aster yellows. Cleared veins and veinlets and pale-yellow veinbanding appear on the involucre bracts and intermediate leaves (plate $5, D$ ). The veinbanding on the bracts of the apical buds fades

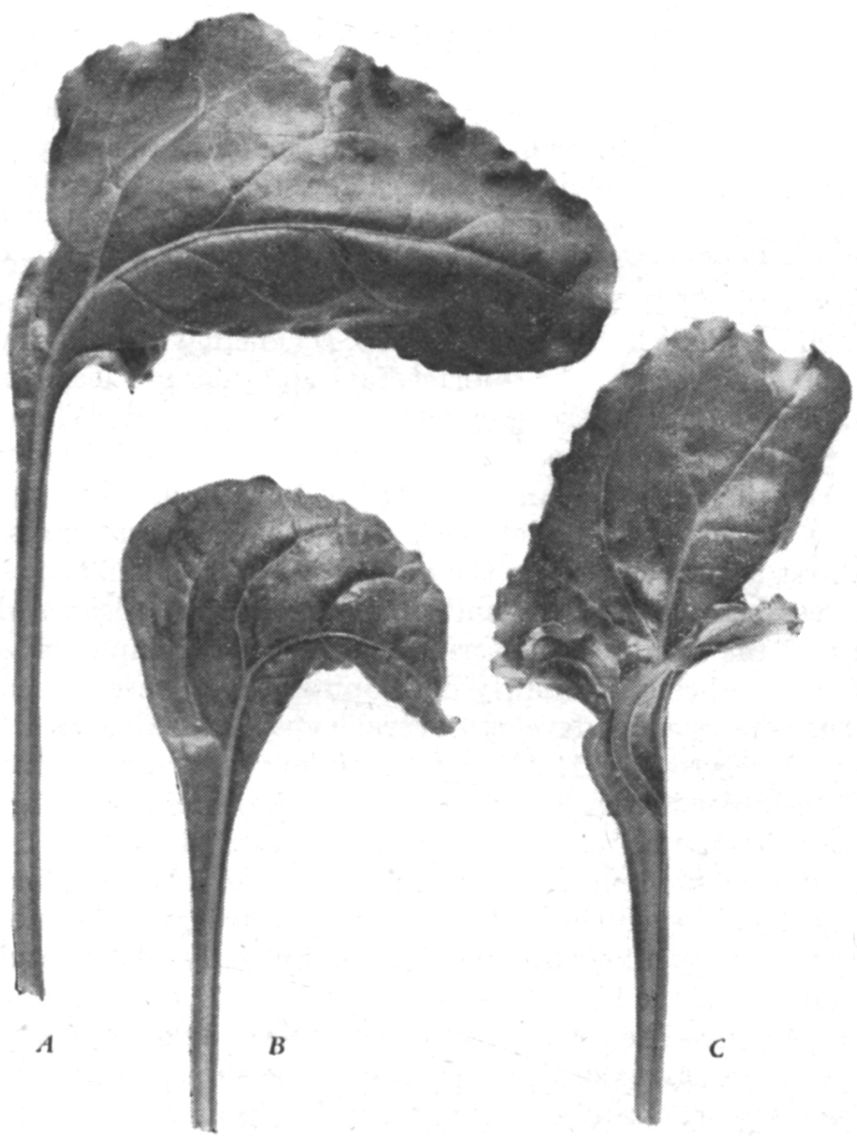

Fig. 1.-Sugar beet (Beta vulgaris) : A, malformed leaf with curved midrib; $B$, asymmetrical leaf with outward rolled margin; $C$, basal margin rolled inward, induced by the causative agent of Xerophloea vanduzeei.

just before the buds begin to expand, and nearly all the axillary shoots become chlorotic.

The involucre bracts may be dwarfed, malformed, and asymmetrical; sometimes the midribs of the older bracts are curved or twisted (plate $6, A, B$ ). The bracts may be linear (plate $6, A, B$ ). Growth is slower in the part of the bract showing cleared venation.

The apical flower bud is somewhat reduced in size; and frequently the petals are curled outward or twisted in a corkscrew (plate $6, D$ ). The buds on the axillary shoots expand only partly or not at all and are dwarfed (plate $5, D$ ). 
Sometimes only part of a bud may open, and the petals may be small and twisted (plate $6, C$ ). Virescence or greening of the flowers may occur-sometimes on only a portion of the flower, the remainder retaining the normal color, as in aster yellows (plate 7).

The most striking symptom induced by the leafhoppers' feeding is the breaking in color of the petals. When the leafhoppers are caged on an aster plant in the late bud stage, the bud expands into a large flower, and the petals begin to break in color (plate $8, A$ ). The breaking consists of white streaks alternating with the normal color of the flowers. The white streaks encompass only the parallel veins at first when examined under a binocular microscope, but soon spread out on each side of the vein. Even if the leafhoppers are removed from the plant, the white gradually becomes more profuse (plate $8, B$ ), and the normal color becomes less and decreases in intensity. Certain of the petals are rolled; others are twisted, sometimes in a spiral (plate $8, D$ ).

\section{ATTEMPTS TO TRANSFER CAUSATIVE AGENT FROM DISEASED PLANTS AND LEAFHOPPERS}

By Beet and Aster Leafhoppers.-No success was achieved in attempts to recover a causative agent from sugar beets showing symptoms induced by Xerophloea vanduzeei and to transfer it to healthy beet seedlings by means of 5 lots of 20 noninfective beet leafhoppers. Likewise, 5 lots of 20 noninfective short-winged and 5 lots of 20 long-winged aster leafhoppers, after feeding on asters showing symptoms, failed to produce symptoms on healthy asters to which they were transferred.

By Mechanical Inoculation.-Only failures resulted from mechanical inoculation with carborundum of the leaves and petioles of 25 healthy beet seedlings and 25 asters with sap extracted from beets and asters that showed symptoms. Inoculations of the midrib and petioles of 10 healthy beet seedlings and 10 asters, using a flame needle with a cotton swab near the point, were also negative. On the other hand, when beets were inoculated with the flamed needle in the crown between the bases of the petioles, the characteristic yellowing and necrosis of the outer leaves developed. No symptoms appeared on the younger leaves. Controls inoculated with sterile distilled water remained healthy. This method of inoculation of the crown of healthy sugar beets with the virus extract from curly-top beets was also successful in the production of this disease (Severin, 1924).

By Salivary Glands.-The salivary glands of each of 10 nymphs crushed in a puncture of each beet root between the bases of 2 petioles by the flamedneedle method of inoculation, induced yellowing and necrosis of one or more outer leaves.

By Noninfective Nymphs.-Nymphs of Xerophloea vanduzeei were transferred singly during the process of hatching from a sugar beet before feeding to a healthy aster; the cleared veinlets appeared on the youngest leaf in 4 to 12 days. This experiment eliminates a virus as the causal agent unless it may be argued that a virus passes through the egg. 


\section{FAILURE TO RECOVER CURLY-TOP AND ASTER-YELLOWS VIRUSES}

Nymphs and adults of Xerophloea vanduzeei that completed the nymphal stages on curly-top beets or infected asters were allowed to feed on healthy beet seedlings and asters respectively. In these healthy plants, lots of 20 noninfective beet leafhoppers and short-winged and long-winged aster leafhoppers failed to recover the viruses and transfer them to 5 healthy beet seedlings and 10 asters.

\section{SYSTEMIC NATURE OF CAUSATIVE AGENT}

An experiment was carried out to ascertain whether the causative agent is systemic. Eight lots of 10 leafhoppers were confined in cellophane cages enclosing a single leaf. Four beet seedlings and four asters were used. One lot of nymphs and one lot of adults were confined on the outer leaves, and one lot of each stage on the inner leaves, of each kind of plant. If a leaf died, the cage was transferred to another similar leaf of the same plant. Two beet seedlings and two asters were used as checks; each was enclosed by a large lawn-covered cage containing either 10 nymphs or 10 adults, the insects being allowed to feed on all portions of the plant except the roots. The experiment was continued for 20 days.

By the eighth day, cleared veinlets of the youngest leaves had appeared on one aster and faintly on one beet seedling, both plants being ones which had leafhoppers on an inner leaf. By the twentieth day, however, all beets and asters showed symptoms. The fact that symptoms developed on the youngest leaf when the insects had fed on an outer leaf indicates that the effect is systemic.

Another method was used to demonstrate the systemic effect of the active principle in asters. A single nymph was confined in each leaf cage (Severin, 1924), which was clamped to a petiole of a basal leaf, in total numbers varying from 1 to 5 on each plant. One case in which 2 nymphs were used per plant will suffice to show the rate of travel of the inciting agent in the aster. In a plant with 2 nymphs the cleared venation appeared within 3 days on an axillary shoot below the petioles on which the nymphs were feeding. The next day the symptom developed on the intermediate axillary shoots; the following day, on the apical shoot; and one day later, on the involucre bracts below the apical flower bud. In one aster plant cleared venation appeared on the leaves of an intermediate axillary shoot above the petiole on which the nymph was feeding, followed by cleared veinlets on the leaves of the next lower secondary shoot. Sometimes the toxic effect produced cleared veinlets on the axillary shoots on one side of the aster, and on the opposite side normal shoots developed. Breaking in the color of the petals appeared after the flower bud expanded and also on flowers of the axillary shoots. Similar results were obtained with the 3 other plants, but the time required for the symptoms to develop on the leaves of the axillary shoots was longer. Seventeen aster plants failed to develop cleared venation, but breaking in color of the flowers occurred. 


\section{INCUBATION PERIOD OF DISEASE}

Nymphal Instars and Adults.-The incubation period of the disease produced by each instar was compared with that induced by the adults. Twelve insects were tested throughout their life history, a healthy aster being provided for each instar and successive asters for each adult as rapidly as symptoms developed. One female failed to induce the disease during adult life. Table 3

TABLE 3

Time Required for Development of First Symptom on Asters Induced by Feeding of Nymphal Instars aNd AduLTS of Xerophloea vanduzeei

\begin{tabular}{|c|c|c|c|c|c|c|c|c|}
\hline \multirow{2}{*}{ Sex and insect no. } & \multicolumn{8}{|c|}{ Time required for cleared venation to develop } \\
\hline & $\begin{array}{l}\text { 1st } \\
\text { instar }\end{array}$ & $\begin{array}{l}2 \mathrm{~d} \\
\text { instar }\end{array}$ & $\begin{array}{l}\text { 3d } \\
\text { instar }\end{array}$ & $\begin{array}{l}\text { 4th } \\
\text { instar }\end{array}$ & $\begin{array}{l}\text { 5th } \\
\text { instar }\end{array}$ & $\begin{array}{l}\text { 6th } \\
\text { instar }\end{array}$ & Adults & Average \\
\hline & days & days & days & days & days & days & days & days \\
\hline \multicolumn{9}{|l|}{ Males: } \\
\hline No. $1 \ldots$ & 8 & 1 & .. & 3 & 4 & . & $12,4,6,15 \ldots \ldots \ldots$ & 9.2 \\
\hline No. $2 \ldots$ & 14 & 11 & 6 & . & 5 & . & $3,6,9,6,8,10,18,32 \ldots$ & 11.5 \\
\hline No. $3 \ldots$ & 9 & 4 & 4 & 6 & 3 & .. & $5,4,3,5 \ldots \ldots \ldots \ldots$ & 4.2 \\
\hline No. $4 \ldots$ & 10 & 5 & 4 & 4 & .. & . & $7,4,7,7,7,10,20 \ldots \ldots$ & 8.9 \\
\hline No. $5 . .$. & . & 5 & 3 & 2 & 2 & . & $5,7,4,4,5,12 \ldots \ldots \ldots$ & 6.2 \\
\hline No. $6 \ldots$ & 6 & 4 & 8 & 5 & . & .. & $5,5,28,16,6,15$ & 11.5 \\
\hline Average.......... & 7.8 & 5.0 & 4.2 & 3.3 & 2.5 & .. & $\ldots \ldots \ldots \ldots \ldots \ldots$ & 8.6 \\
\hline \multicolumn{9}{|l|}{ Females: } \\
\hline No. $1 \ldots$ & .. & 3 & 5 & 7 & 3 & . & $19,9 \ldots \ldots \ldots \ldots \ldots$ & 14.7 \\
\hline No. $2 \ldots$ & .. & 3 & 4 & 3 & 2 & . & $22,5 \ldots \ldots \ldots \ldots \ldots$ & 13.5 \\
\hline No. $3 \ldots$ & 7 & . & . & . . & 6 & . & $*$ & $\ldots$ \\
\hline No. $4 \ldots \ldots \ldots \ldots$ & 8 & 3 & 4 & 7 & 3 & .. & $6,5,3 \ldots \ldots \ldots \ldots \ldots$ & 4.6 \\
\hline No. $5 \ldots \ldots \ldots \ldots$ & .. & 13 & 3 & .. & 6 & 6 & $\begin{array}{r}5,6,5,5,5,8,8,5,15 \\
4,5,6,7 \ldots \ldots \ldots \ldots\end{array}$ & 6.5 \\
\hline No. $6 \ldots \ldots \ldots \ldots$ & 8 & 3 & 4 & 5 & 4 & . & $5,6,14 \ldots \ldots \ldots \ldots \ldots$ & 8.3 \\
\hline Average................ & 3.6 & 4.2 & 3.3 & 3.7 & 4.0 & 6.0 & $\ldots \ldots \ldots \ldots \ldots \ldots \ldots$ & 7.8 \\
\hline
\end{tabular}

* Insect failed to induce the disease during adult life.

shows the results obtained. The average time for symptoms to develop was less for every nymphal instar than for the adult.

Overwintering Adult Color Forms.-The adult color forms that wintered over in the greenhouse on asters were transferred singly to healthy asters to determine whether there was any difference in the incubation period of the disease. Two or 3 females of each color form were used. Only 1 male was studied in the experiment. The number of days required for the cleared venation to appear on asters with each color form was as follows :

Green females : No. $1-40,7,6$ days, No. 2-33 days. No. 3-23 days. Average, 21.8 days.

Pink females : No. $1-9,11,10,19,6$ days. No. $2-17,11,5,6$ days. No. $3-23$ days. Average, 11.7 days.

Cream females : No. $1-43$ days. No. $2-29$ days. Average, 36.0 days.

Brown male : $13,18,5,5,8,8,7,5,4,5,11,7$. Average, 8.0 days. 


\section{SUMMARY}

The eggs were deposited in the petioles, midrib, and veins of sugar-beet leaves. One nymph passed through six molts; all others through five. Each instar can be determined accurately by measurements of the head across the compound eyes. The color of the first instar is gray; of the second, greenish gray; and of the third, fourth, and fifth instars, green. The adults have four color forms-namely, gray males and green, pink, and cream-colored females.

On sugar beets the feeding of Xerophloea vanduzeei induces cleared veinlets, previously considered a reliable symptom of curly top. On asters it induces cleared venation with yellow veinbanding, stunting of the plants, development of axillary shoots from the bud in the axil of the leaves, and virescence of the flowers, all symptoms of aster yellows. The most striking effect produced by the feeding of the leafhoppers is breaking in the color of the petals.

Only failures resulted from mechanically inoculating the leaves, midrib, and petioles of healthy beet seedlings and asters, using carborundum or a flame needle with a cotton swab near the point. When beets were inoculated with the flamed needle in the crown between the bases of the petioles, the characteristic yellowing and necrosis of the outer leaves developed. No symptoms appeared on the younger leaves.

The salivary glands of each nymph that was crushed into a beet root by the flamed-needle method induced yellowing and necrosis on one or more outer leaves.

Known vectors of curly top and aster yellows failed to transmit the causative agent from plants showing symptoms of Xerophloea vanduzeei injury to corresponding healthy plants.

In both sugar beets and asters the active principle is systemic and is presumed to be due to a toxic salivary secretion.

The average time for symptoms to develop on asters was less for every instar than for the adult, and longer for three color forms of overwintering females.

\section{ACKNOWLEDGMENTS}

Credit is due to P. M. Oman, Division of Insect Identification, Bureau of Entomology and Plant Quarantine, Washington, D. C., for the determination of the species. 


\section{LITERATURE CITED}

BALL, E. D.

1918. Leaf burn of the potato and its relation to the potato leafhopper. Science 48:194. 1919. The potato leafhopper and its relation to hopper burn. Jour. Econ. Ent. 12:149-55.

BINKLEY, A. M.

1929. Transmission studies with the new psyllid-yellows disease of solanaceous plants. Science $70: 615$.

CARTER, W.

1932. The pineapple mealy bug, Pseudococcus brevipes, and wilt of pineapples. Phytopathology $23(3): 207-42$.

1932. The spotting of pineapple leaves caused by Pseudococcus brevipes, the pineapple mealy bug. Phytopathology 23(3):243-59.

1936. The symbionte of Pseudococcus brevipes in relation to a phytotoxic secretion of the insect. Phytopathology 26(2):170-83.

1939. Injuries to plants caused by insect toxins. Bot. Rev. 5(5):273-326.

EYER, J. R.

1922a. Preliminary note on the etiology of potato tip burn. Seience, n. s. 55:180-81.

$1922 b$. Notes on the etiology and specificity of potato tip burn produced by Empoasca mali Baron. Phytopathology 12:181-84.

Fenton, F. A.

1921. Progress report of the season's work on the production of potato tip burn. Jour. Econ. Ent. 14:71-83.

Fenton, F. A., and Albert Hartzell.

1923. Bionomics and control of the potato leafhopper, Empoasca mali Le Baron. Iowa Agr. Exp. Sta. Res. Bul. 78:379-440.

GERMAR, E. F.

1839. Drei neue Gattungen der Cicadinen. In: Zeitschrift für die Entomologie 1(1): 187-92. (See especially p. 190.) Friedrich Fleischer, Leipzig, Germany.

Granovskr, A. A.

1928. Alfalfa "yellow top" and leafhoppers. Jour. Econ. Ent. 21:261-66.

1930. Differentiation of symptoms and effects of leafhopper feeding on histology of alfalfa leaves. Phytopathology 20:121.

Iто, $\mathrm{K}$.

1938. Studies on the life history of the pineapple mealybug Pseudococins brevipes (Ckll.). Jour. Econ. Ent. 31:291-98.

Johnson, H. W.

1934. Nature of injury to forage legumes by the potato leafhopper. Jour. 'Agr. Res. 49:379-406.

LAWSON, P. B.

1931. The genus Xerophloea in North America (Homoptera, Cicadellidae). Pan-Pacific Ent. 7(4):159-69.

MEDLER, T. J.

1941. The nature of injury to alfalfa caused by Empoasca fabae (Harris). Ent. Soc. Amer. Ann. 34(2):439-50.

Monteith, J., JR., and E. A. Hollowell.

1929. Pathological symptoms in legumes caused by the potato leafhopper. Jour. Agr. Res. 38:649-77.

Poos, F. W.

1929. Leafhopper injury to legumes. Jour. Econ. Ent. 22:143-53.

Poos, F. W., and N. H. WHEELER.

1934. On the hereditary ability of certain insects to transmit diseases and to cause disease-like injuries to plants. Jour. Econ. Ent. 27(1) :58-69.

1943. Studies of host plants of the leafhoppers of the genus Empoasca. U. S. Dept. Agr. Res. Bul. $850: 1-51$.

RAwlins, T. E., and C. M. Tompkins.

1936. Studies on the effect of carborundum as an abrasive in plant virus inoculations. Phytopathology $26: 578-87$. 
RighaRds, B. L., and H. L. BLood.

1933. Psyllid yellows of potato. Jour. Agr. Res. 46(3):189-216.

ROBINSON, L. RAY, and B. L. RICHARDS.

1931. Anasa wilt of cueurbits. Phytopathology 21:114.

SEVERIN, H. H. P.

1924. Curly leaf transmission experiments. Phytopathology 14:103-7. Summary 14:123. 1929a. Curly-top symptoms on the sugar beet. California Agr. Exp. Sta. Bul. 465:1-35.

1.929b. Yellows disease of celery, lettuce, and other host plants transmitted by Cicadula sexnotata (Fall.) Hilgardia 3(18):543-82.

1930. Life-history of beet leafhopper, Eutettix tenellus (Baker), in California. Univ. California Pubs., Ent. 5:37-88.

1940. Potato naturally infected with California aster yellows. Phytopathology 30(12): 1049-51.

1942. Infection of perennial delphiniums by California-aster-yellows virus. Hilgardia $14(8): 411-30$.

Severin, H. H. P., and J. H. Freitag.

1933. Some properties of the curly-top virus. Hilgardia 8(1):1-48.

Shapovalov, M.

1929. Tuber transmission of psyllid yellows in California. Abs. in Phytopathology $19: 1140$.

SмIтH, F. F.

1933. The nature of the sheath material in the feeding punctures produced by the potato leafhopper and the three-cornered alfalfa hopper. Jour. Agr. Res. 47:475-85.

SMITH, F. F., and F. W. Poos.

1931. The feeding habits of some leafhoppers of the genus Empoasca. Jour. Agr. Res. $43(3): 267-85$

Stahl, C. F., and E. Carsner.

1918. Obtaining beet leafhoppers nonvirulent as to curly-top. Jour. Agr. Res. 14:393-94.

TENG, S. C.

1931. A preliminary report on the studies of certain diseases of cotton. Sci. Soc. China, Biol. Lab. Contrib., Bot. Ser. 6(9):117-26.

WANG, S. C., and H. YUAN.

1924. Studies of crytosis in cotton. Natl. Southeastern Univ. Rept. 1923-24, pp. 1-28. Cotton Res. Lab. (In Chinese; original not seen, reviewed by Teng, 1931.)

Williams, C. B.

1921. Froghopper blight of sugar cane in Trinidad. Trinidad and Tobago Dept. Agr. Mem. 1:1-170.

WITHYCOMBE, C. L.

1926. Studies on the aetiology of sugar cane froghopper blight in Trinidad. I. Introduction and general survey. Ann. Appl. Biol. 13:64-108.

Woops, A. F.

1900. Stigmonose: a disease of carnations and other pinks. U. S. Dept. Agr. Div. Veg. Physiol. and Path. Bul. 19:1-30. 
PLATES 


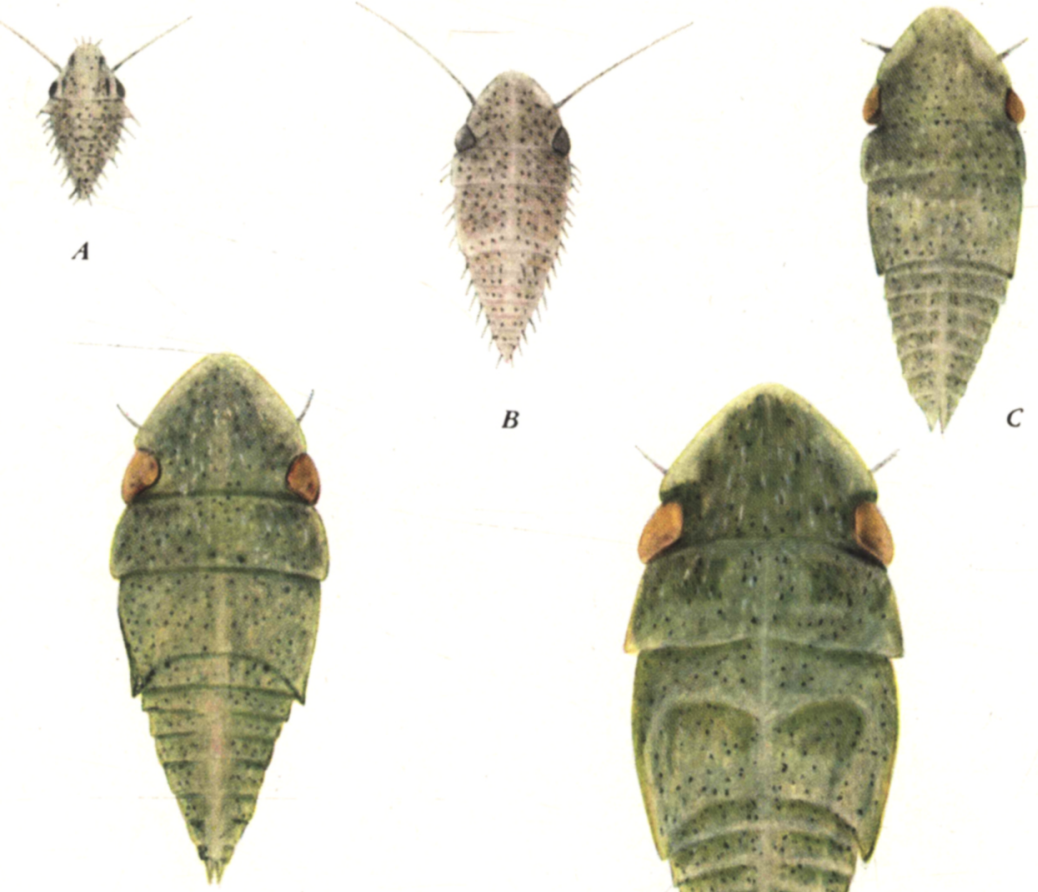

D
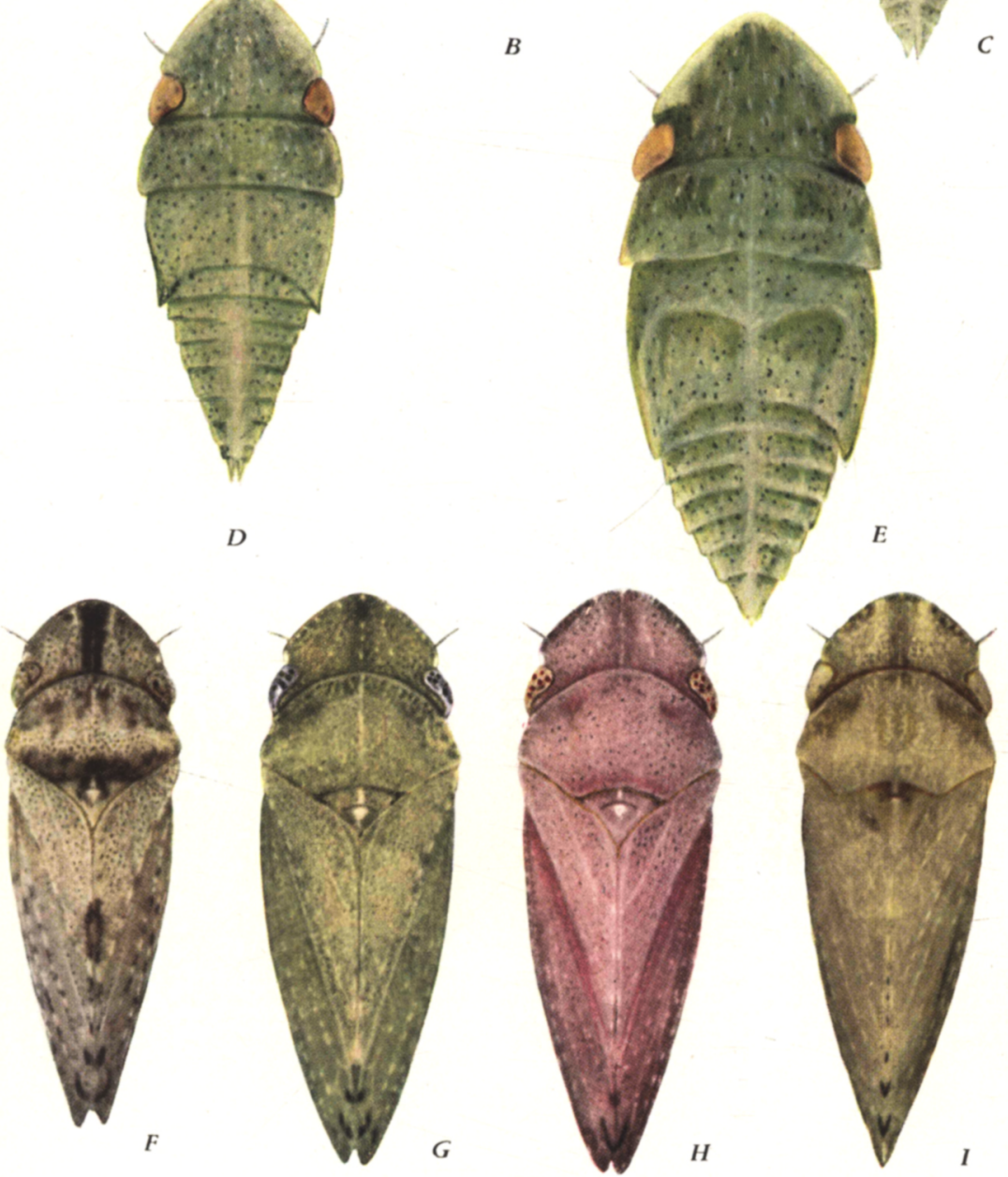

Plate 1.-Color patterns of nymphal instars and adults of Xerophloea vanduzeei Law.: A, first instar, gray with numerous hairs on thorax and abdomen; $B$, second instar, greenish gray; $C, D, E$, third, fourth, and fifth instars, green; $F$, adult male, brown; $G$ to $I$, adult females-green, pink, cream. $(A$, photographed 1 day after hatching; the others, 1 day after the molt.) 


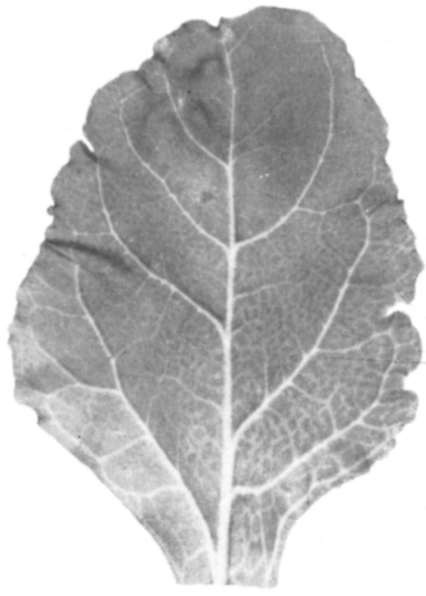

$A$

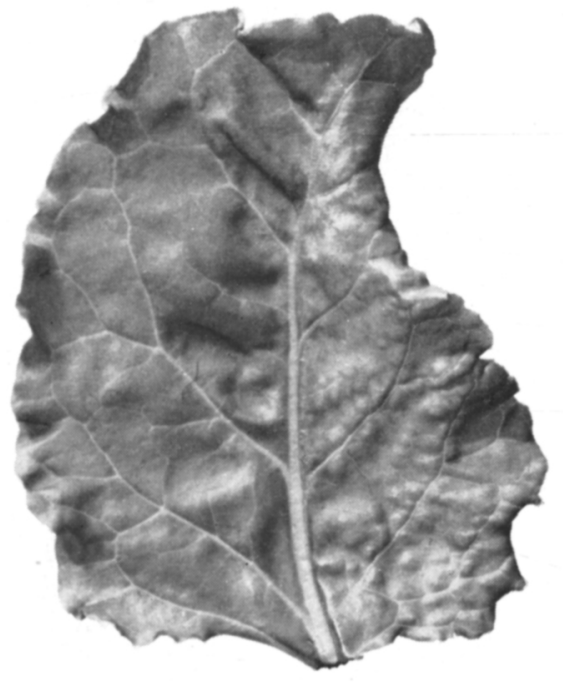

C

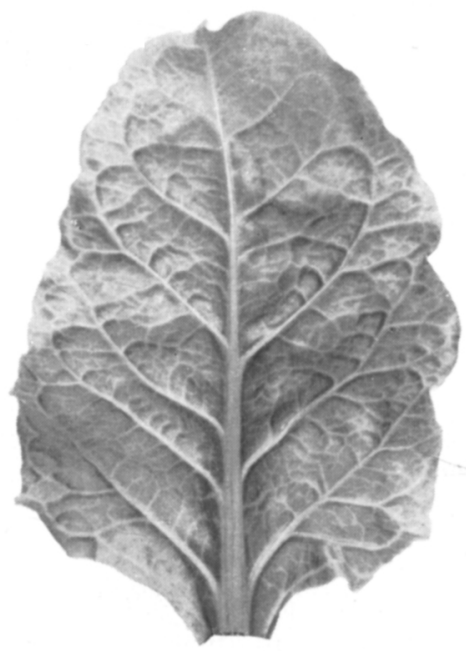

B

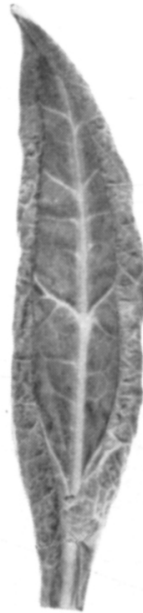

$D$

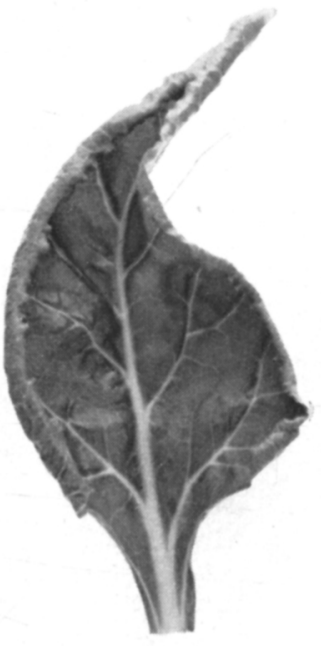

E

Plate 2-Sugar beet (Beta vulgaris): A, younger or irner leaf showing cleared veins and reinlets; $B$, swelling of veinlets, with protruding midrib and lateral veins on the lower surface of the blade; $C$, interveinal protuberances on the upper surface of the blade; $D$, inward rolling of the margin of the youngest leaf and cleared veinlets; $E$, inward rolling of the margin and curved midrib. 

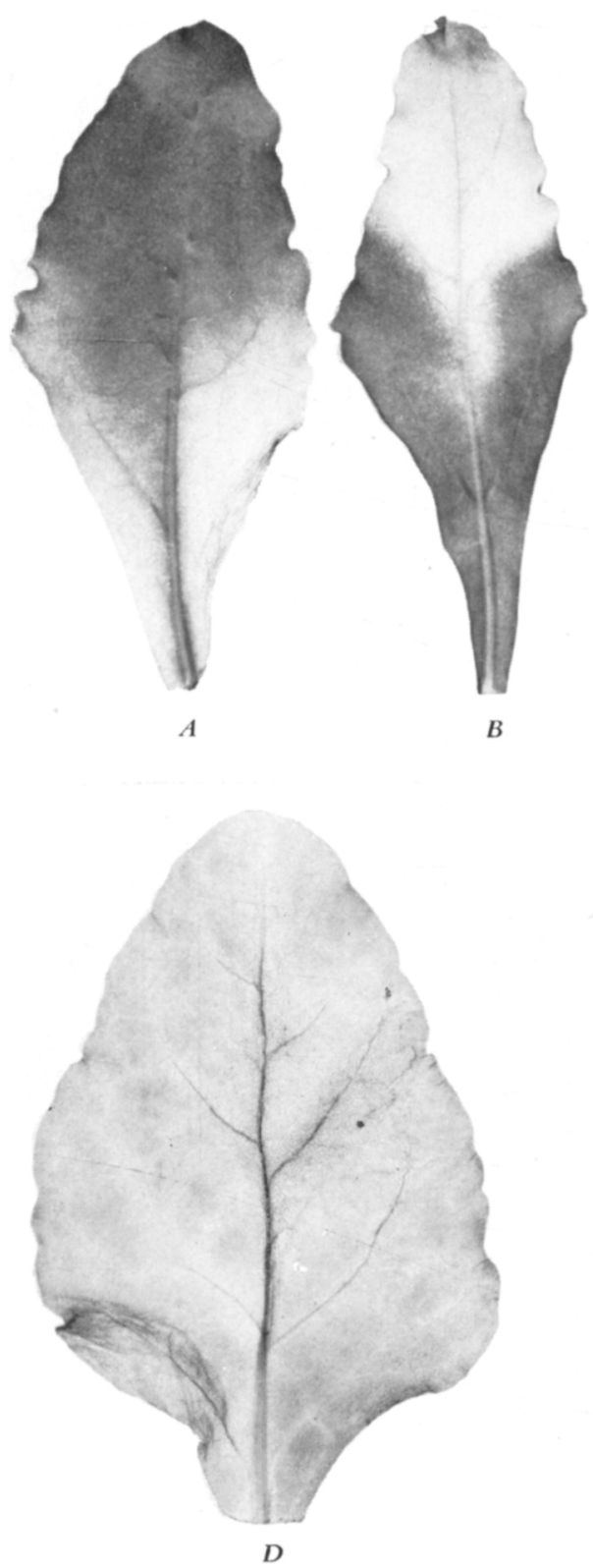
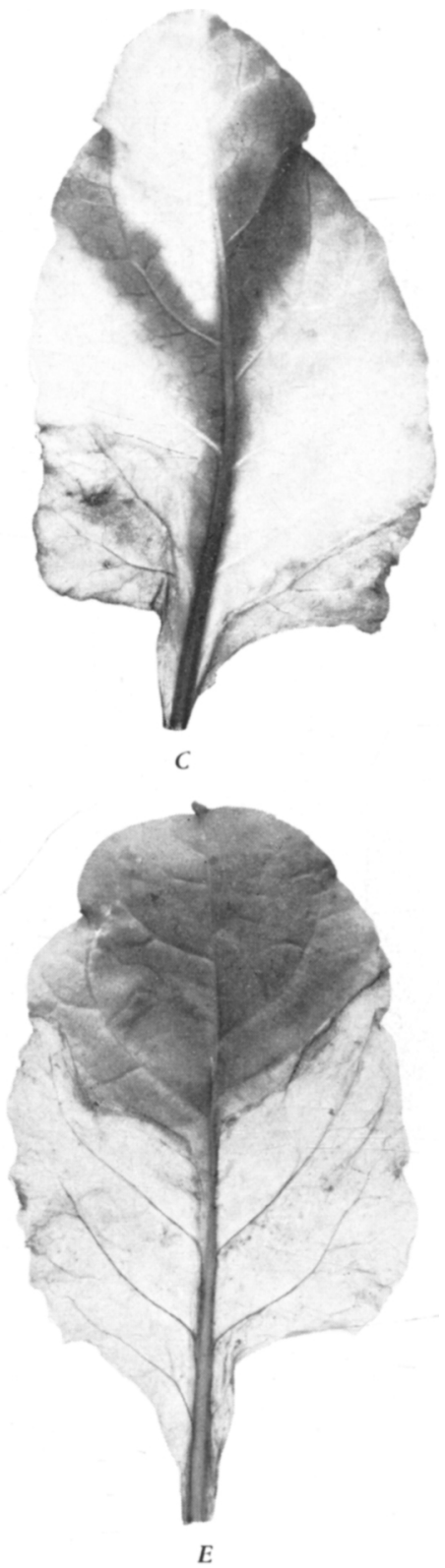

Plate 3.-Sugar beet (Beta vulgaris) : $A, B, C$, yellowing of basal and apical portions of blade and parts along both sides of the midrib; $D$, necrosis of midrib and veins; $E$, dried basal and middle portion of blade, with apical part still green. 


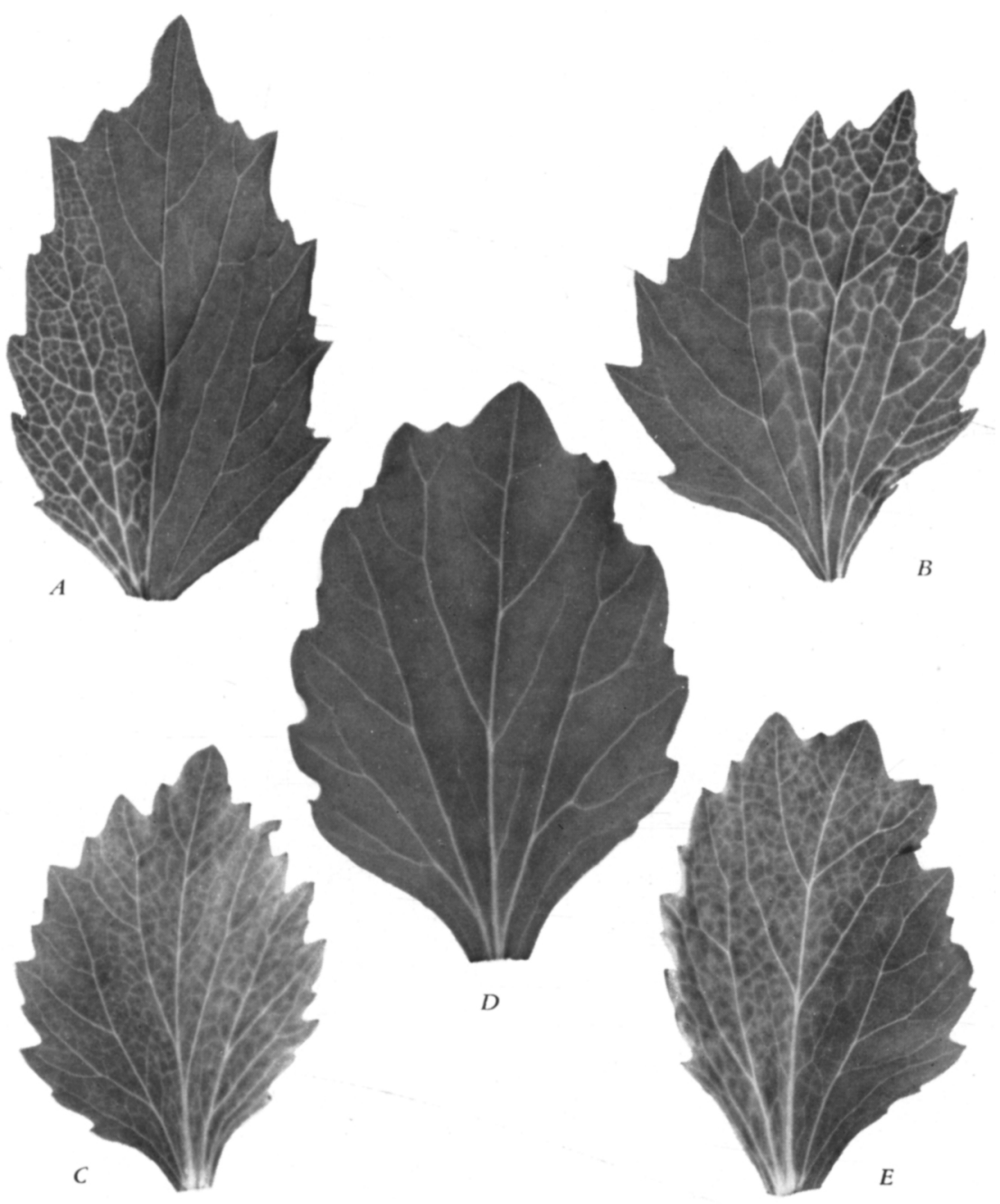

Plate 4.-China aster (Callistepluus chinensis): $A, B$, cleared veins and veinlets induced by toxic secretion of Xerophloea vanduzeei; $C$, leaf from healthy check or control plant; $D, E$, cleared venation caused by the aster-yellows virus. 


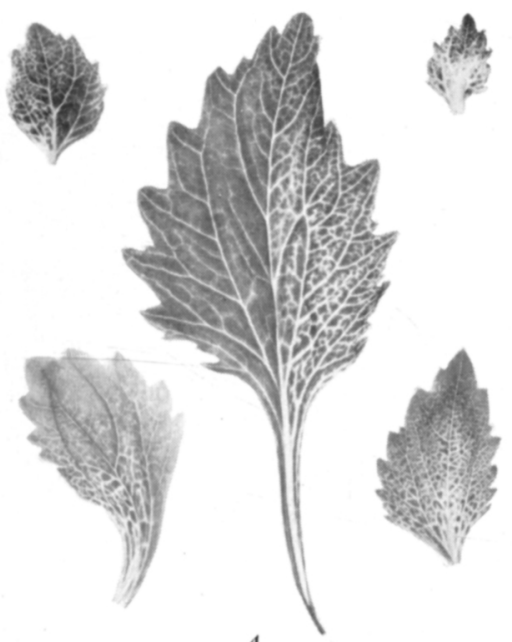

$A$

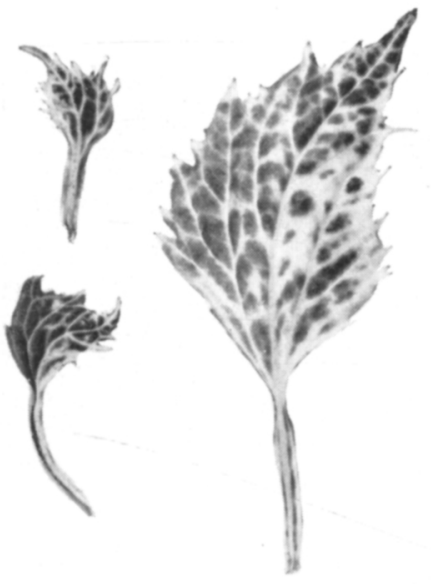

C

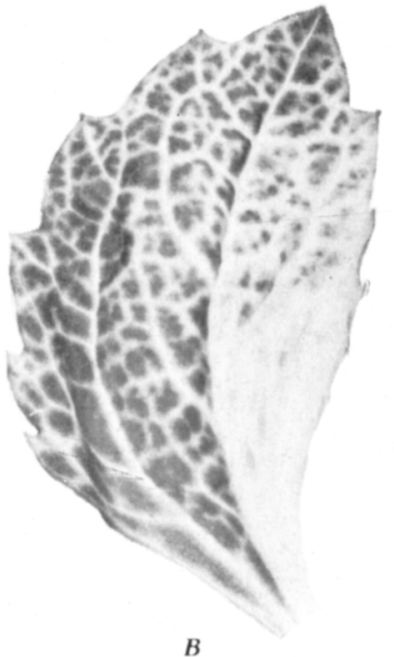

B

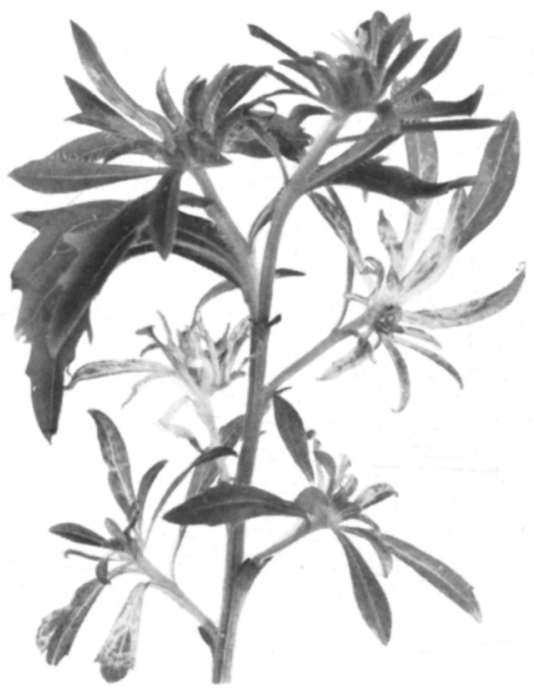

$D$

Plate 5.-China aster (Callistephus chinensis): A, cleared veins and veinlets, asymmetrical leaves; $B$, cleared venation with yellow veinbanding; $C$, left, two leaves showing asymmetry and pale-yellow veinbanding; right, small, green, interveinal, blisterlike elevations; $D$, axillary shoots showing paleyellow veinbanding or chlorotic involucre bracts and intermediate leaves. 

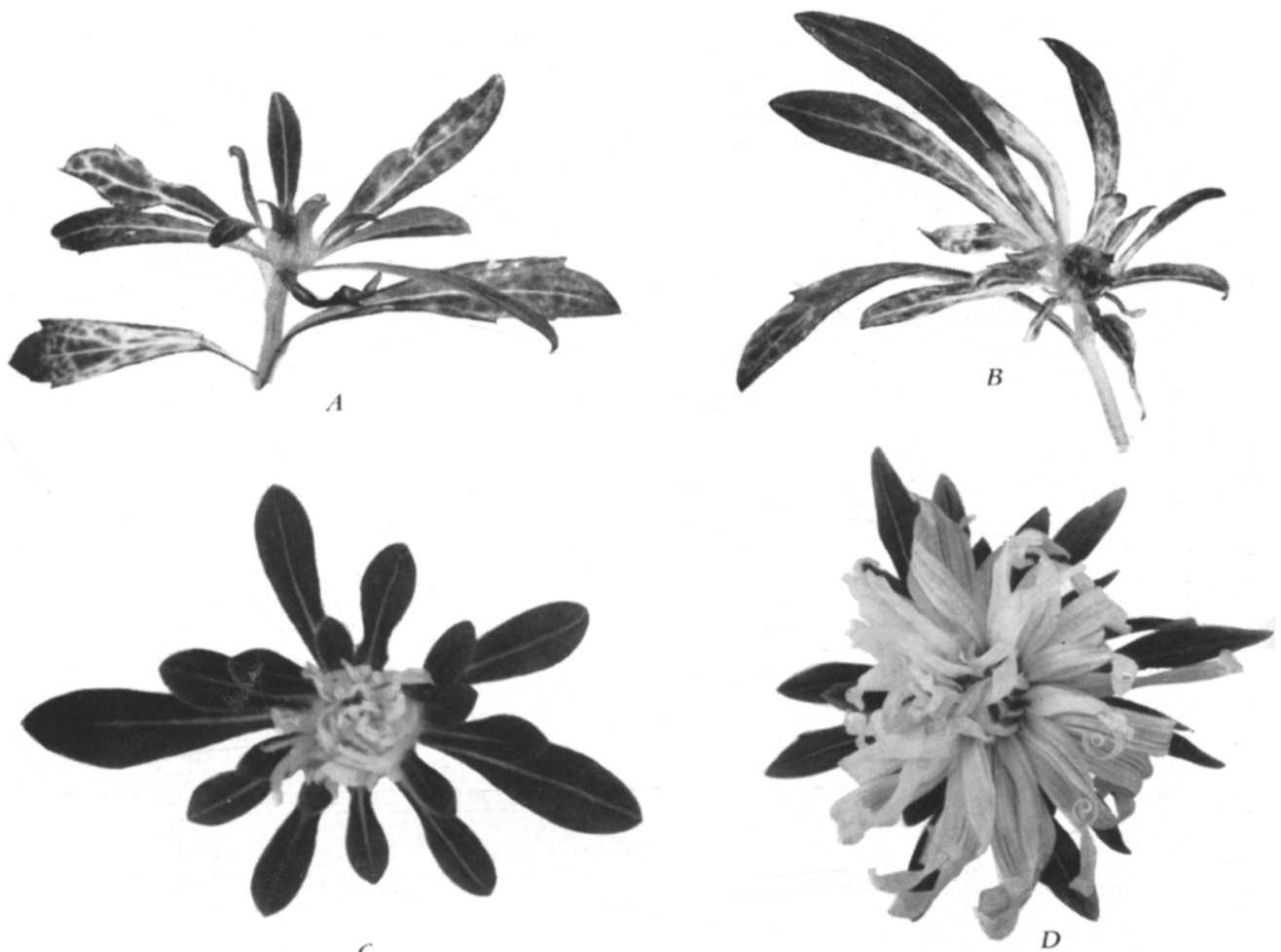

C

Plate 6.-China aster (Callistephus chinensis): A, axillary shoot showing pale-yellow veinbanding and curved or twisted linear bracts; $B$, axillary shoot showing chlorotic involucre bracts and intermediate leaves near the basal region; $C$, small flower buds with small, twisted petals; $D$, flower with petals curled outward or twisted in a spiral. 


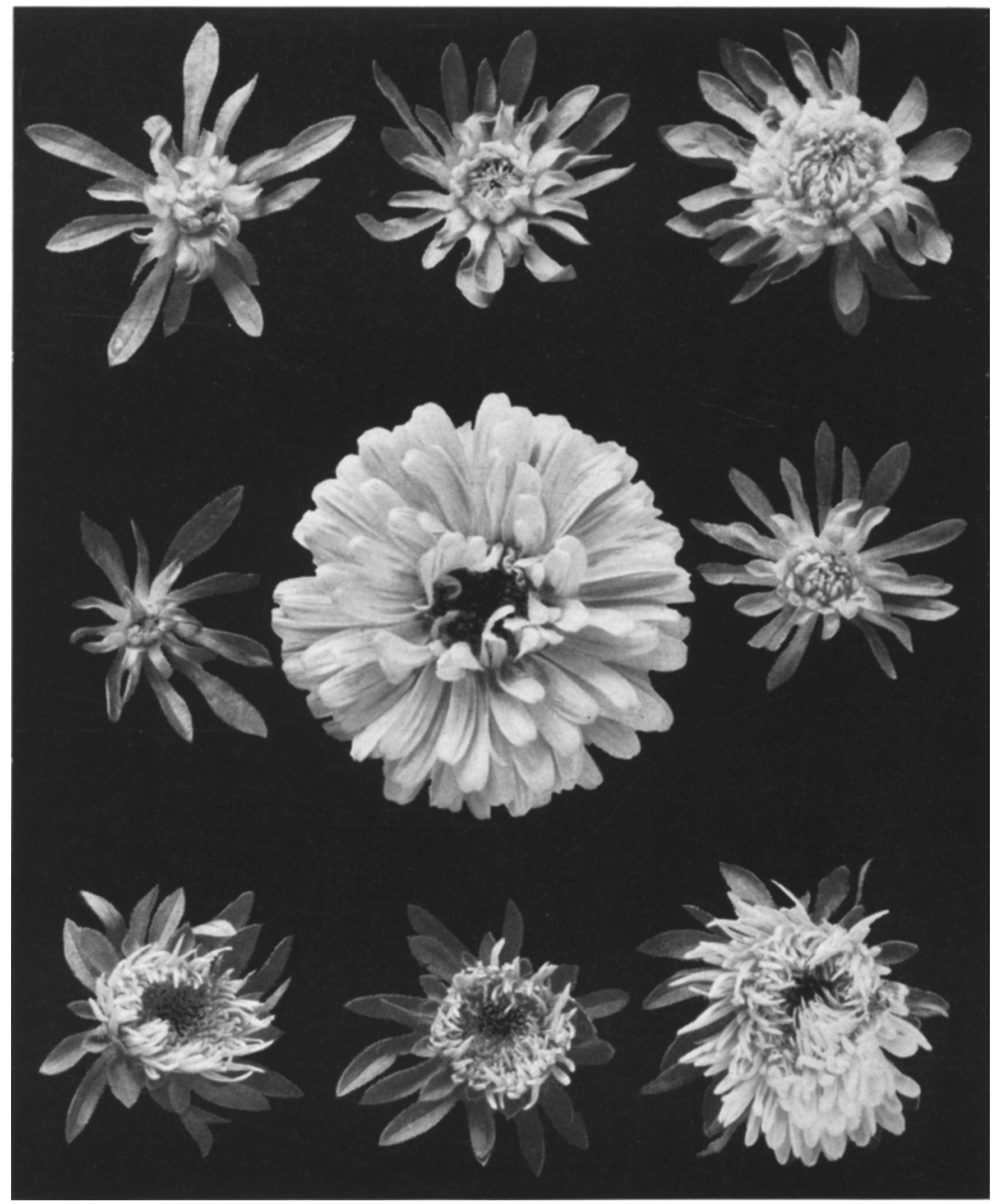

Plate 7.-China aster (Callistephus chinensis) : center, normal flower from a check or control plant. Grouped around it are eight abnormal flowers from aster plants infected with aster yellows, some showing greening of the flowers and others having a portion of the flower green or white while the remainder retains the normal color of the variety. 

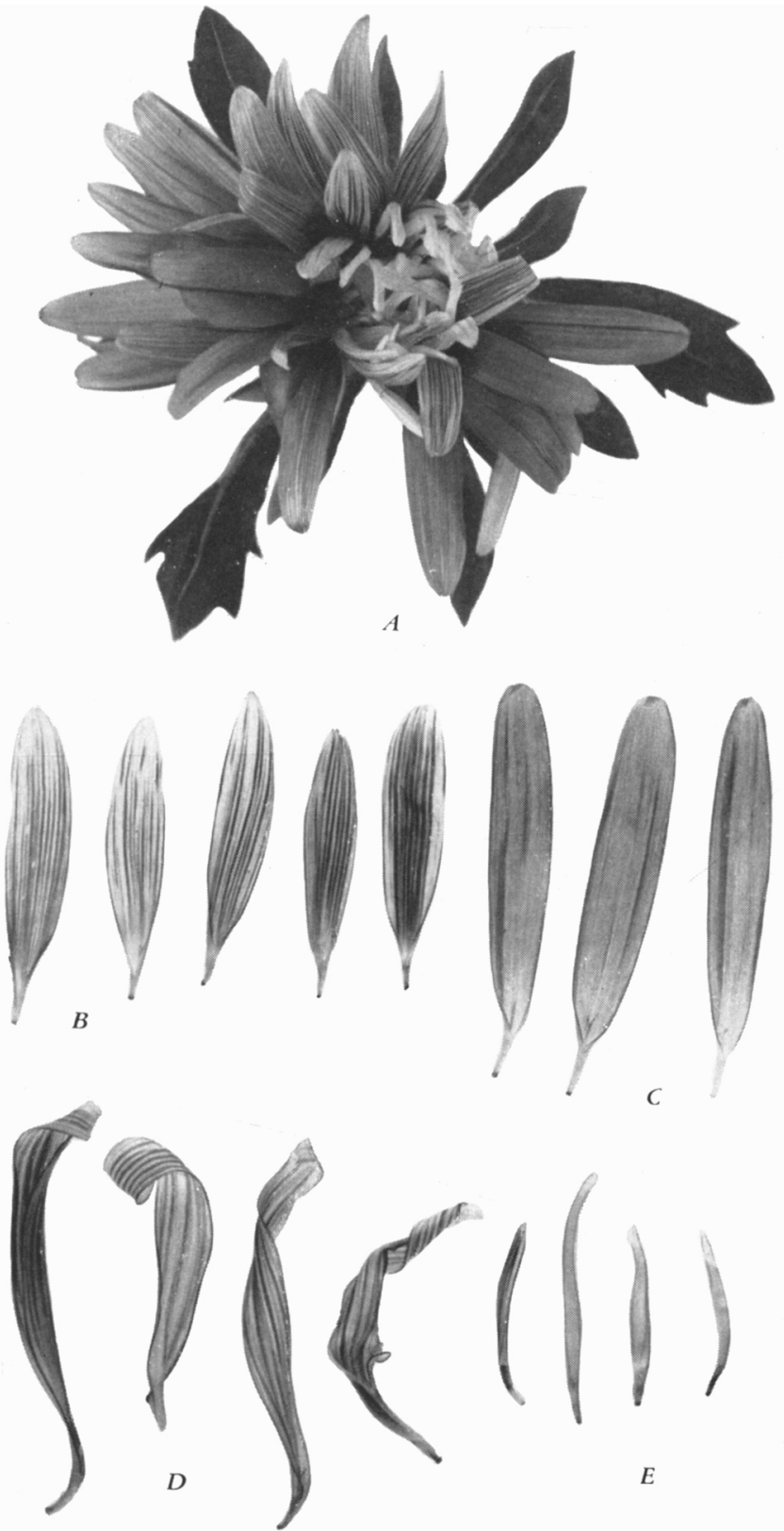

Plate 8.-China aster (Callistephus chinensis): A, flower showing breaking in color induced by the causative agent of Xerophloea vanduzeei; $B$, five petals showing breaking in color, with white streaks alternating with the normal color; $C$, three petals from healthy check or control plant; $D$, four petals showing rolling or twisting, sometimes in a spiral; $E$, four linear petals. 